\title{
An Overview of the Right to Strike Phenomenon in South Africa
}

\author{
Kola O. Odeku
}

\author{
Faculty of Management and Law, School of Law, University of Limpopo, South Africa
}

\author{
Doi:10.5901/mjss.2014.v5n3p695
}

\begin{abstract}
Marikana massacre in South Africa came about as a result of the vicious strike actions by the mining workers. Marikana is just one of the numerous strike actions by various trade unions and their members. In most cases, the strikes were usually triggered by demand for increase in wages. Undoubtedly, workers have rights to strike within the limit of the law but the reality on the ground portrays a different phenomenon. Most strike actions have been embarked upon in flagrant violation of the rules of the game. The consequences of unprotected strike have serious implications on socio economic growth and at the same time producing violent and criminal enterprises in the course of the actions. At the end of the day, everyone will be loosers because in most of the cases, trade unions have not been seen to use and explore the possibility of collective bargaining to resolve trade dispute. While this paper subscribes to the right of workers to strike, it argues that the rights of other parties are as important as the rights of the striking workers
\end{abstract}

Keywords: Industrial disputes, competing rights, consequences and remedies, collective bargaining

\section{Introduction}

In South Africa, these days, virtually all sectors of the economy are experiencing strike actions usually embarked upon by the labour unions (Seidman, 1994). While some of the strike actions are legal and protected within the ambit of the law, others have been found to be illegal and frivolous (Olivier, 2002). These types of illegal strikes are prominent in the mining industry which accounts for substantial foreign exchange earnings of the country and which also hire a huge number of workers (Altman, 2006). Violent strikes have produced a lot of ugly incidences during the apartheid regime and it seems not to be declining during post-apartheid democratic dispensation. Williams (1988) describes the situation thus "Strikes were frequently accompanied by violence and Strikers were regularly beaten, arrested and shot by the police. Strike breakers were intimidated, beaten and sometimes murdered by striking workers. Labour analysts ascribed the high levels of workers' violence to the conditions under which trade unions organised and engaged in collectivebargaining during the apartheid era - in particular, the failure to fully institutionalise industrial conflict, and, more broadly, the absence of political rights which imbued industrial action with a strong political dimension. The implication was that with the political incorporation of workers into a post-apartheid democracy, and with the full institutionalisation of industrial conflict in new post-apartheid labour legislation, strike violence and the high levels of mass militancy which sustained it, would decline. This has not happened. Strikes have increasingly been accompanied by heavy-handed police action - beatings, shooting with rubber bullets, arrests - while intimidation, assaults and murders of strike breakers have been a persistent feature of many large-scale strikes" (Williams, 1988).

In South Africa, the right to strike is a constitutional right and it is generally regulated by section 23 of the Constitution of the Republic of South Africa Act 108 of 1996 and other labour legislation that govern employment relationships (Bhorat and Cheadle, 2009). The Labour Relations Act of 1995 (LRA) defines a strike in section 213 as "the partial or complete concerted refusal to work, or the retardation or obstruction of work, by persons who are or have been employed by the same employer or by different employers, for the purpose of remedying a grievance or resolving a dispute in respect of any matter of mutual interest between employer and employee, and every reference to work in this definition includes overtime work, whether it is voluntary or compulsory."

Similarly, South Africa laws recognise the right of workers to strike as enshrined in various international, national and regional instruments (Simmons, 2009). This is why it is legal for employees to collectively come together to form trade unions for the purpose of collective bargaining (Olson, 2009) and other common causes such as wage negotiations, better conditions at workplaces, common voice on concerns related to welfare of the workers and so on ( Dundon et al., 2004).

Nowadays, in South Africa, the current trends in resolving industrial disputes is to threaten to or out rightly embark 
on a strike action against the employer (Jacobs, 2013). Some scholars have argued that this has become a major tool being used by the trade unions to arm-twist and force the employers to go into bargaining and negotiations with the employees otherwise the employers will not take the employees seriously (Cappelli, 1999). Others are in support of strike to press for workers' demands in industrial dispute, aaccording to Worugji and Archibong (2009) "strike is accepted as an indispensable component of a democracy and a stimulus to social dialogue in industrial relations..., workers have continued to use strikes in expressing their grievances."

It must however be pointed out that the threat to strike and strike action have to be made or implemented within the confine of the law otherwise it will amount to violation of the rules of the game and there will be consequences. The right to strike is a two edged sword, while workers have right to strike, non-striking workers and the employers also possess rights recognise within the rules locally and internationally. Romeyn (2008:1) writes that "the International Labour Organisation (ILO) attempts to ensure that the right of parties to take industrial action is balanced against other fundamental rights of workers, employers and the public-such as the freedom of non-strikers to work and the right to protection of property and personal safety. This is sometimes misunderstood by governments who, in attempting to protect the 'public interest', impose constraints that effectively limit any successful industrial action and thereby, impair the important role of industrial action in collective bargaining."

To this end, in South Africa, the right to strike is an integral part of collective bargaining and freedom of association in pursuit of common cause for the betterment of the members of the striking workers, non-striking workers and the employers (Harmer, 1988).

There have been arguments in some quarters that despite the numerous laws in support of the right of workers to strike, when it comes to the issue of implementation of the laws, they have been interpreted or implemented in such a way that favour employees over the employers particularly in South Africa (Weiler and Mundlak, 1993). This is not peculiar to South Africa, in Nigeria, Worugji and Archibong (2009) write that "based on the lopsided desire to protect general services and the business interests of the employer over and above the interests of the worker," strike actions are usually repressed by the people in authority.

Worugji and Archibong (2009) have argued that "strike should not be repressed in industrial relations but should continue to be in order to encourage social dialogue and workers' participation in the democratic management of the enterprise and the economy as a whole." Against the backdrop of asserting the right to strike, unions have taken advantage and at every opportunity especially if their demands are not met, resort to strike without exploring other measures like collective bargaining to find ample solution to the dispute (Yates, 2009). Sometimes, the unions are pains in the skin as they make unreasonable and outrageous demands of higher percentage increase in the salaries and wages of their members without going into negotiations with the employers. If the employers decline to accept such demands, the unions will deliberately go on strike in order to frustrate the employers (Hyde, 1993). Currently, some mine workers and their trade unions are adamant $t$ on the wage increase to R12, 500.00 per month or nothing thereby frustrating all avenues to resolve the wage dispute. Sometimes, if the employers assess the magnitude of loss that will be incurred if production and work stop, they will be forced to accept the unreasonable and outrageous wage increase (Milgrom and Roberts, 1990). These are the dilemmas of using strike actions to unreasonably bargain and they cut across all sectors in South Africa (Coker, 1981).

\section{Literature Review}

It is generally accepted that a "right to strike has been widely recognised as a fundamental element of stable collective bargaining. Industrial action is one of the essential means available to employees to promote and protect their economic and social interests and resolve industrial disputes. Employers may also use industrial action (for example through lockouts)" (Romeyn, 2008). In the words of Davidmann (1996) "a workforce which cannot withdraw its labour at will is either oppressed or enslaved. A free people have the right to strike and can exercise this right, supporting those who exercise it. The right to strike, and the extent to which people can strike, are fundamental freedoms which distinguish a participative government or management from an authoritarian one. The right to strike includes the basic provision that the contract of employment is suspended for the duration of the strike, that a striker has not broken his contract of employment by striking, that those on strike may not be penalised for striking. The right to strike needs to be protected by a written, secure and enforceable constitution."

However, this does not give the person or party exercising the right to strike an open cheque. There are rules and regulations governing strike actions and if they are transgressed, there are consequences for these as explained by Romeyn (2008:5) thus "an ability to take industrial action is consistent with the parties taking responsibility for their 
industrial outcomes and an important means of overcoming a bargaining impasse. It may also be considered a necessary corollary of a healthy collective bargaining system and indeed, a healthy democracy."

Trade unions and workers don't just embark on strike action even if it is their right to do so. Unresolved industrial disputes usually trigger strike actions. Although all avenues to avert and prevent strikes must have been explored by the parties, in some cases, no avenue is explored. The unions or sometimes the members will just declare strike action. Providing useful insight on how to resolve industrial dispute without necessarily embarking on strike, Romeyn (2008:3) points out that "a right to strike generally arises in relation to the resolution of interest disputes. Many bargaining systems recognise that grievance or dispute resolution procedures (for example, involving a stepped process of discussion, conciliation or mediation, perhaps ending with arbitration) are appropriate to the resolution of rights disputes arising during the term of an agreement. The inclusion of such provisions within agreements can help to ensure that grievances are amicably resolved as quickly as possible and at the lowest possible level, without the need to resort to industrial action. This approach is consistent with the philosophy that employers, employees and their representatives should take responsibility for determining mutually beneficial terms and conditions of employment to apply in their workplaces and should adhere to those settlements during the life of their agreement."

The aggressive nature of the union officials in pressurising wage increase and using wild cat strike as the last resorte is aptly captured by Friedman (2007) thus "union officials try to enforce wage restraint, the consequence is likely to be wildcat strikes." The business owners will feel the heat and in most cases could result to huge economic loss. If the striking workers are violent and vicious, the likelihood of destruction of the employer's property and infliction of bodily injuries to non-participating workers are not ruled out. In the case of South African Transport and Allied Workers Union (SATAWU) and Others v Moloto N.O and Another, the minority view was in sympathy with the plight of the employer and they vehemently averred that "it is nigh impossible to conceive how the employer will prepare properly for the impending power play. How will it make an informed decision as to whether or not to yield to the employees' demands? And, if it resists, how will it take proper steps to protect its business, the employees and the public and engage meaningfully in pre-strike regulatory discussions regarding issues such as picketing rules?"

While strike may be used for trade negotiation, collective bargaining offers a better solution and it is also the right of the workers to collectively bargain. This is tacitly recognised in the LRA and constitutionally approved in 1996 in South Africa (Bendix, 2010). The right to collective bargaining and by implication, including the right to strike are guaranteed under the ILO and other international instruments (Swepston, 1998).

A right to strike which covers the range of forms of industrial action has been recognised by international organisations of which South Africa is a member and it is also enshrined in Article 8 of the United Nations International Covenant on Economic, Social and Cultural Rights, which provides that "1. The States Parties to the present Covenant undertake to ensure: (a) The right of everyone to form trade unions and join the trade union of his choice, subject only to the rules of the organization concerned, for the promotion and protection of his economic and social interests. No restrictions may be placed on the exercise of this right other than those prescribed by law and which are necessary in a democratic society in the interests of national security or public order or for the protection of the rights and freedoms of others; (b) The right of trade unions to establish national federations or confederations and the right of the latter to form or join international trade-union organizations; (c) The right of trade unions to function freely subject to no limitations other than those prescribed by law and which are necessary in a democratic society in the interests of national security or public order or for the protection of the rights and freedoms of others; (d) And the right is exercisable in conformity of the laws of the particular country 2. This article shall not prevent the imposition of lawful restrictions on the exercise of these rights by members of the armed forces or of the police or of the administration of the State. 3. Nothing in this article shall authorize States Parties to the International Labour Organisation Convention of 1948 concerning Freedom of Association and Protection of the Right to Organize to take legislative measures which would prejudice, or apply the law in such a manner as would prejudice, the guarantees provided for in that Convention."

However, it is pertinent to point out that there is no express reference in the ILO Convention to the right to strike (Gernigon, 1998). This notwithstanding, the ILO supervisory bodies have consistently averred that (Romeyn, 2008) "a right to strike has been widely recognised as a fundamental element of stable collective bargaining. Legislative frameworks have long been recognised internationally as having an important role to play in equalising power bases and promoting stable bargaining by establishing the 'rules for the game."

There is strike when a group of workers who are in dispute with their employer withdraws their labour and refuse to work (Burton et al., 1969). The South African Constitutional court has given tacit support to the right of the workers by pronouncing in the case of National Union of Metalworkers of South Africa and Others v Bader Bop (Pty) Ltd and the Minister of Labour 2003 (2) BCLR 182 (CC), that the "Constitutional Court held that it is of importance for the dignity of 
workers who in our constitutional order may not be treated as coerced employees. The court further held that, it is through industrial action that workers are able to assert bargaining power in industrial relations. The court concluded by indicating that the right to strike is an important component of a successful collective bargaining system." Similarly, in the recent case of South African Transport and Allied Workers Union (SATAWU) and Others v Moloto and Another the court held that "the right to strike is protected in the Constitution at least partly in recognition of the fact that there are disparities in the social and economic power held by employers and employees. Employers have far more power than individual employees and in order to redress the inequality in social and economic power in employer/employee relations, employees are granted the right to strike to even out the playing field."

Although section 23 of the Constitution guarantees rights to strike, section 65 of the LRA imposes restrictions and limitations to the right (van Rensburg and van Rensburg, 2013). Section 23 when read with the LRA clearly spell out the procedures to be followed to make a strike legitimate and legal (the shorthand for this is 'protected strike.' There are consequences for embarking on unprotected strikes and the employer has remedies in the Act.

An exception to the rule is people performing Essential Services. They are barred under the laws from embarking on strike. In section 213 of the LRA, an essential service is defined as "service, the interruption of which endangers the life, personal safety or health of the whole or any part of the population, the parliamentary service, and the South African Police Services (SAPS)."

Under the law, the Essential Services committee is conferred with the responsibility of considering and determining which service qualifies as an essential service. Once a service is qualified as an 'essential service', then such a service is prohibited from engaging in a strike action (Basson, 2009). Although section 65 of the LRA limits the right to strike, it has been observed by the Constitutional court that "not all employees employed by the SAPS are engaged in essential services." And as such, the court has confirmed that not all staff employed by the South African Police Service (SAPS) is prohibited from striking. The court held that only those SAPS members employed under the South African Police Service Act (SAPSA) are engaged in providing essential services under the LRA. Sections 65(1)(d)(i) and 71(10) of the LRA prohibits employees engaged in essential services from engaging in strike action. Hofmeyr (2011) indicates that "the Constitutional Court's judgment confirms the sanctity of the right to strike - a hard-fought right that is part of the very fibre of our employment law framework. The judgment reinforces the central role that collective bargaining plays in the workplace. Employers seeking to avoid the pitfalls of collective bargaining may have to look elsewhere rather than classifying its service as an essential service in the light of this judgment."

The implications of the above stated limitations show that there is no unlimited right (Glendon, 2008). Where one's rights stops another begins. Hence, the society can restrict or limit a right in the interests of the society generally, or by competing rights of others (McHarg, 1999).

For a strike to be held as protected, it must follow the procedure laid down by section 64 of the LRA when there is a dispute. The dispute must be referred to council or the (CCMA). Thereafter a certificate must be issued stating that the dispute remains unresolved or the dispute remains unresolved for 30 days since referral despite conciliation. The court held in the case of Tiger Wheels Babelegi (Pty)Ltd v NUMSA (1999) 20 ILJ 677(LC) that the employer/union must therefore give the other party 48 hours written notice before commencement of strike or lock-out. However if the state is the employer, the employer must be given 7 days' notice before commencement of the strike.

For the sake of an argument, some scholars have expressed the view that there are circumstances in which a strike may be protected although the prescribed procedures have not been complied with and in other instances a special procedure may be required (du Plessis, 2007). These positions would have been subscribed to if they are supported by legal authority or specific provisions in the law that allows for deviation. What the court demands is compliance with the law without attempting to import or interpret the law wrongly. Against this backdrop, in the case of South African Transport and Allied Workers Union (SATAWU) and Others v Moloto N.O and Another the court warned that "we should not restrict the right to strike more than is expressly required by the language of the provision, unless the purposes of the Act and the section on "a proper interpretation of the statute ... imports them. The relevance of a restrictive approach is to raise a cautionary flag against restricting the right more than is expressly provided for. Intrusion into the right should only be as much as it is necessary to achieve the purpose of the provision and this requires sensitivity to the constraints of the language used."

Appraising how the Judges fared in the case of South African Transport and Allied Workers Union (SATAWU) and Others v Moloto N.O and Another, De Vos (2012) indicates that "the majority seem to be decidedly more progressive by assuming that the right to strike contained in the Bill of Rights should be limited as little as possible in order to ensure the levelling of the playing field between employers and employees. They would therefore oppose an interpretation of the legislation that would impose limitations on this right unless such limitations are expressly stated in the Labour Relations 
Act itself."

According to Mcllroy (1984) "as long as our society is divided between those who own and control the means of production and those who only have the ability to work, strikes will be inevitable because they are the ultimate means workers have of protecting themselves." According to Weintraub and Thornton (1976), "a strike is an investment in employee bargaining power since it helps them play a role in the decision making process on matters affecting them." Novitz (2003) states that strike can be justified not only to improve working conditions but also influence the way that an enterprise is run. Worugji and Archibong (2009) point out that "sustained social dialogue and workers' participation in the democratic management of the enterprise is a panacea for industrial peace and sustainable economic development." The right to strike and the freedom of association enable the workers to collectively defend their interests (Hanslowe and Acierno, 1981). If an individual is legally entitled to refuse to work, the coordinated withdrawal of labour should be permitted and protected (Novitz, 2003). Mcgregor argues that the strikes are used by employees to back up their demands in promoting and defending their employment-related interests.

$\mathrm{du}$ Toit is of the opinion that the purpose of a strike is to remedy a grievance or resolve a dispute, the continuation of a strike is dependent on the existence of such grievance or dispute, where the employer concedes to the demandsthe 'substratum' of the strike disappears and the strike is terminated(du Toit, 2005).

Davidmann (1996) is also of the opinion that "people are enslaved when they are forced to work through need and have to work to survive. They are enslaved to the extent to which they are forced to accept mere survival existence in return for the work they do. They are free to the extent to which they are able to choose freely between one employer and another, to the extent to which they are backed by a comprehensive system of social security and services if falling on difficult times."

Although these authors are correct in that strikes are essential for democracy within the workplace (Nkabinde, 2009), they are however not addressing the issue of where the employees make unreasonable demands and then engage in a strike action solely to frustrate the employer.

\section{Consequences of a Strike Action}

Even though the right to strike is recognized under the laws in South Africa, Section 67 of the LRA explicitly provides for the consequences of a strike action embarked upon against the spirit and purport of the law (Klug, 2000). The consequences are outlined thus "(a) Employees may not be dismissed for striking; (b) Employees who are involved in a protected strike do not commit a delict or breach their contract of employment. This is however does not apply if the act itself does constitute a criminal offence; (c) The employer is obliged to remunerate strikers, except if the remuneration includes payment in kind and the workers request such payment; (d) Employees may be dismissed for misconduct during a strike; (e) Employees may be retrenched as a consequence of the strike; (f) Civil proceedings may not be instituted against a person for his or her involvement in a protected strike. (g) Any act in furtherance of a protected strike which is in contravention of the Basic Conditions of Employment Act does not constitute an offence; (h) Failure by a union to conduct a ballot may not give rise to litigation which will affect the legality or protection of a strike; and some implications apply in respect of the employer's ability to employ replacement workers."

With regard to an unprotected strike, the consequences are well articulated in section 68 of LRA as follows "(a)The Labour Court may interdict the strike; (b) The Labour Court may award just and equitable compensation for any loss attributable to the strike, having regard to a number of considerations; -whether the strike or lock-out was premeditated; whether attempts were made to comply with the provisions of the chapter on strike law and the extent of those attempts; -Whether the strike or lock-out was in response to unjustified conduct by another party to the dispute; -whether there was compliance with a Labour Court order or interdict restraining any person from participating in industrial action. interests of orderly collective bargaining; the duration of the strike or lock-out; and - the financial position of the employer, trade union or employees. (c) Involvement in an unprotected or prohibited strike may constitute a fair reason for dismissal, provided that a fair procedure is followed. In the case of a prohibited or unprotected strike the labour Court has exclusive jurisdiction."

There is no law, whether national or international that prohibits the following and adherence to the procedure. The procedures must be adhered to anytime the trade union wants to call for a strike. This position has been given a judicial approval in the case of Mzeku v Volkswagen SA (Pty) Ltd (2001 ILJ 1575 (LAC) where the court observed that "there is no provision in ILO Conventions 87 and 98 to the effect that employees can resort to a strike as and when they please without following any procedures that may be laid down by national law or that national law falls foul of these conventions if it prescribes procedures that must be followed before there can be an exercise of the right to strike." 


\section{Ending the Persistent Strikes in South Africa}

While it is generally acceptable that the right to strike is the most precious tool the strikers have against the employer, this right is not absolute as it is limited in laws regulating labour disputes. There have been instances of unreasonable and incessant strikes in South Africa that have negatively impacted on other sectors because they were not prevented. Kheel (1973:35) asserts that "when a major strike threatens to disrupt an important service, a sense of hopelessness often pervades the public. The publicity about impasse sometimes tends to make our entire system of industrial relations appear chaotic. The public wants to know, why these disputes cannot be prevented? If the parties themselves cannot agree, why shouldn't they be told what to do? Why can we not have a law that prevent these disruptions?"

In South Africa, a strike action may as well drag action without any intervention and all other areas of services would be disrupted. While government is supposed to be seen to be neutral regarding labour disputes, when the dispute is as a result of the sector sustaining the economy such as mining, the government could intervene by ensuring that the dispute is either prevented before it started or resolved amicably after it has started. Therefore, collective bargaining should be explored a means of labour dispute resolution.

\section{Exploring Collective Bargaining as an Alternative to Strike}

Collective bargaining is defined as "the process through which a labour union and an employer negotiate the scope of the employment relationship" (Burton, 2007). A collective bargaining agreement is a holistic document usually subscribed to by all the parties and outlines how issues including disputes would be resolved should they arise. Collective agreement serves as an alternative to strike action in industrial dispute resolution because it "allows workers and employers to reach voluntary agreement on a wide range of issue" (Marginson and Sisson, 1996).

Kheel (1973:35) write that "a collective bargaining is a highly disciplined process, conducted against a background of rules that are generally honoured. The strike itself is part of the discipline. It makes collective bargaining work by inducing decisions on differences that might otherwise drag on interminably."

Bargaining enables each party to make concessions on burning issues and mutually agreed on the way forward in order to bring about a conclusion on resolution of a dispute to the logical acceptable conclusion. It is a sort of trade off as it makes the workers to get wage increase, however this increase is tied to increase in output and performance.

More importantly, "collective bargained solutions often involve change. Change works best when both sides agree to the future direction. That is the reason why collective bargaining is so appropriate for organisations undergoing change" (Romney, 2008).

Contemporary labour law jurisprudence and scholarly works have shown that collective bargaining is a viable alternative to strike. The essence of CCMA in South Africa is to promote bargaining as opposed to strike. The parties in disputes are therefore enjoin to tow this path as it makes dispute resolution cost effective and produce a better result unlike strike. It is likened to a win-win situation. All the parties involve will have to make some concessions but still benefit.

\section{Conclusion}

The right to strike is guaranteed under the law but it should be exercised in accordance with the laid down procedures that stipulates the right. If it is exercised contrary to the law, there are consequences. However, scholarly literature has shown that collective bargaining is a viable alternative to strike. The employers and trade unions are therefore enjoined to explore the means of collective bargaining to resolve disputes.

\section{References}

Altman M 2006. Low wage work in South Africa-Labour Markets and Social Policy. From http://www.cosatu.org.za/docs/subs/2007 Iwork.pdf. (Retrieved on January 2, 2013).

Basson AC 2009. Essential Labour Law. Cape Town, South Africa: Labour Law Publications.

Bendix S 2010. Industrial relations in South Africa. Cape Town, South Africa: Juta \& CO Ltd.

Bhorat H Cheadle H 2009. Labour reform in South Africa: Measuring regulation and a synthesis of policy suggestions. From http://www.dpru.uct.ac.za/sites/defaultffiles/image_tool/images/36/dpru\%20wp09-139.pdf. (Retrieved on April 3, 2014).

Burton JF, Krider C, Collins H, Ewing KD, McColgan A 1969. The Role and Consequences of Strikes by Public Employees. Yale Law Journal, 79:418-506. 
Burton WC 2007. Collective Bargaining. From http://legal-dictionary.thefreedictionary.com/collective+bargaining. (Retrieved on March 17, 2014).

Cappelli P 1999. The new deal at work: Managing the market-driven workforce. Boston, USA: Harvard Business School Press.

Chicktay MA 2006. Placing the right to strike within a Human Rights frame work. Obiter, 27(2): 344-350.

Coker C 1981. Collective Bargaining as an Internal Sanction: The Role of US Corporations in South Africa. The Journal of Modern African Studies, 19(4): 647-665.

Collins H, Ewing KD, McColgan A 2005. Labour Law Text and Materials. From http://www.amazon.co.uk/Labour-Law-MaterialsSecond-Edition/dp/1841133620. (Retrieved on May 17, 2013).

Davidmann M 1996. ,'Slavery,compulsion and freedom: the right to withdraw one's labour. From http://www.solhaam.org/articles /right.html. (Retrieved on June 4, 2013).

De Vos P 2012. Sharp divisions on the Constitutional Court about the right to strike. From http://constitutionallyspeaking.co.za/sharpdivisions-on-the-constitutional-court-about-the-right-to-strike/. (Retrieved on 28 March, 2014).

du plessis JV 2007. A practical Guide to Labour Law, Cape Town, South Africa:LexisNexis.

du Toit D 2005. Labour Relations Law: A comprehensive Guide. Cape Town, South Africa: LexisNexis,Butterworths.

Dukes R 2011. The right to strike under the UK: more than a slogan? Industrial Law Journal, 40(3): 302-311.

Dundon T, Wilkinson A, Marchington M, Ackers P 2004. The meanings and purpose of employee voice. The International Journal of Human Resource Management, 15(6):1149-1170.

Ewing KD, Hendy J 2012. The Dramatic Implications of Demir and Baykara. Industrial Law Journal, 39(1):2-51.

Friedman M 2007. The Social Responsibility of Business Is to Increase Its Profits. Corporate Ethics and Corporate Governance, 1:173178.

Gernigon B, Odero A, Guido H 1998. ILO Principles Concerning the Right to Strike. International Labour Review, 137:441-449.

Glendon MA 2008. Rights talk: The impoverishment of political discourse. From $h l=e n \& \mid r=\& i d=4 b 50-0 v 0 m o w c \& o i=f n d \& p g=p r 9 \& d q$ =xwwaalqv0drkgwwsvt0my\#v. (Retrieved on June 1, 2013).

Hanslowe KL, Acierno JL 1981. Law and Theory of Strikes by Government Employees. Cornell Law Review, 67:1055-1064.

Harmer L 1988. Right to Strike: Charter Implications and Interpretations. University of Toronto Faculty of Law Review, 47:420-429.

Hofmeyr CD 2011. Certain SAPS employees may go on strike - Constitutional Courts says. From http://www.polity.org.za/article/certainsaps (Retrieved on May 11, 2013).

Hyde A 1993. Employee Caucus: A Key Institution in the Emerging System of Employment Law. Chicago-Kent Law Review, 69:149158.

Jacobs M 2013. What Factors Contributed to the Failure of the 2011 Municipal Strike? From http:/luctscholar.uct.ac.za/pdf 198733 jocobs_m.pdf. (Retrieved on April 3, 2014).

Kheel TW 1973. Exploring Alternatives to the Strike- Is the Strike Outmoded. Monthly Labour Review, 96:35-44.

Klug H 2000. Constituting Democracy: Law, Globalism and South Africa's Political Reconstruction. Cambridge, UK: Cambridge University Press.

Marginson P Sisson K 1996. Multinational companies and the future of collective bargaining: a review of the research issues. European Journal of Industrial Relations, 2(2):173-197.

McGregor M, Dekker A, Budeli M, Manamela E, Manamela T 2012. Labour Law Rules. From http://www.littlewhitebakkie.com/LabourLaw-Rules!.htm. (Retrieved on January 4, 2014).

McHarg A 1999. Reconciling Human Rights and the Public Interest: Conceptual Problems and Doctrinal Uncertainty in the Jurisprudence of the European Court of Human Rights. The Modern Law Review, 62(5):671-696.

Mcllroy J 1984. Strike! How to fight. How to win. From http://www.getcited.org/pub/102404729. (Retrieved on April 7, 2013).

Medisetty S 2004. A right to strike: a legitimate illegality. From http/l:www.legalserviceindia.com./articles/legill.htm. (Retrieved on January 4, 2014).

Milgrom P, Roberts J 1990. Bargaining costs, influence costs, and the organization of economic activity- Perspectives on positive political economy. Cambridge, UK: Cambridge University Press.

Morris GS 1994. Freedom of Association and the Interests of the State. In Ewing KD, Gearty CA, Hepple BA. Human Rights and Labour Law, Essays for Paul O'Higgins. New York, USA: Mansell Publishing Limited.

Nkabinde B 2009. Right to Strike, an Essential Component of Workplace Democracy: Its Scope and Global Economy. Maryland Journal of International Law, 24:270-279.

Novitz T 2003. International Protection of the Right to Strike: A Comparative Study of Standards Set by the International Labour Organization and the Council of Europe. New York, USA: OUP Publication.

Olivier M 2002. The South African Constitution and freedom of religion : some labour law imperatives and implications. Dutch Reformed Theological Journal, 43(3\&4):530-542.

Olson M 2009. The logic of collective action: public goods and the theory of groups. From http://books.google.co.za/books?hl=en\&lr= \&id=jv8wTarzmsQC\&oi=fnd\&pg=PR9\&dq. (Retrieved on January 16, 2013).

Romeyn J 2008. Striking a balance: the need for further reform of the law relating to industrial action. From aphnew.aph.gov.au. http://aphnew.aph.gov.au/binaries/library/pubs/rp/2007-08/08rp33.pdf. (Retrieved on February 7, 2013).

Seidman G 1994. Manufacturing militance: workers' movements in Brazil and South Africa, 1970-1985. From $\mathrm{hl}=$ en\&lr=\&id=knaD9dttHJQC\&oi=fnd\&pg=PR9\&dq=In. (Retrieved on March 4, 2013).

Simmons BA 2009. Mobilizing for human rights: international law in domestic politics. Cambridge, UK: Cambridge University Press. 
Swepston L 1998. Human Rights Law and Freedom of Association: Development through ILO Supervision. International Labour Review, 137:169-178.

van Rensburg A, van Rensburg D 2013. Nurses, industrial action and ethics Considerations from the 2010 South African public-sector strike. Nurse Ethics, 20(7): 819-837.

Weiler P, Mundlak G 1993. New Directions for the Law of the Workplace. The Yale Law Journal, 102(8):1907-1925.

Weintraub AR RJ Thornton 1976. Why Teachers Strike: The Economic and Legal Determinants, Journal of Collective Negotiations in the Public Sector, 5: 193.206.

Weintraub AR, Thornton RJ 1976. Why Teachers Strike: The Economic and Legal Determinants. Journal of Collective Negotiations in the Public Sector, 5(3):193-206. Williams G 1988. Social Dynamics Transformation: Critical perspectives on Southern Africa. Journal of African studies, 14(1):57-66.

Worugji I, Archibong JA 2009. The Repressive Face of Law to Strike in Nigeria: Hope for Industrial Peace? Journal of Commonwealth Law and Legal Education, 7(2): 113-132.

Yates MD 2009. Why unions matter. New York, USA:Monthly Review Press. 